\title{
FORMULASI DAN AKTIVITAS ANTIOKSIDAN MASKER WAJAH GEL PEEL OFF EKSTRAK METANOL BUAH PEPAYA (Carica papaya L.)
}

\author{
Liza Pratiwi ${ }^{1}$, Sri Wahdaningsih ${ }^{1)}$ \\ ${ }^{1)}$ Program Studi Farmasi, Fakultas Kedokteran, Universitas Tanjungpura, Pontianak \\ email : lyza_pratiwi@yahoo.com/085643182838
}

\begin{abstract}
Gel peel off facial mask is one of the alternative dosage that can improve the comfort to use and is expected to increase antioxidant activity from papaya fruit. Papaya has antioxidant activity due to antioxidant components such as beta-carotene, vitamin $C$, lycopene. The purpose of this research is to know that methanol extract of papaya fruit can be formulated into gel peel off facial mask preparation, determining polivinyl alkohol (PVA) that used for gelling agent gel peel off facial mask concentration with physical, chemical, and antioxidant activity with the best $I C_{50}$ value. The method used in the extraction is maceration with methanol solvent. PVA used with concentration are 2,5\%; 8,75\%; and 17,5\%. The Physical test include organoleptic test, adhesion test, spreading test and the chemical test with $\mathrm{pH}$ test. Based on the result of the research, it can be concluded that the methanol extract of papaya fruit can be formulated into gel face mask preparation, the formula with PVA concentration of $8,75 \%$ fulfill organoleptic rules, with adhesion test 20,16 seconds $\pm 2,90$, spreading test 10,2 cm $\pm 1,28, p H$ value 7,13 $\pm 0,06$ with the physical and chemical properties of gel peel off facial mask methanol extract of papaya fruit, and formula with concentration 8,75\% PVA has the highest antioxidant activity with $I_{50}$ value $80,52 \mu \mathrm{g} / \mathrm{mL}$ that include as strong antioxidant.
\end{abstract}

Keywords: gel peel off facial mask, methanol extract of papaya fruit, $P V A, I C_{50}$.

\begin{abstract}
ABSTRAK
Masker gel peel off merupakan salah satu alternatif sediaan yang dapat meningkatkan kenyamanan penggunaan dan diharapkan dapat meningkatkan aktivitas antioksidan buah pepaya. Pepaya memiliki aktivitas antioksidan karena komponen-komponen antioksidan seperti betakaroten, vitamin C, likopen. Tujuan penelitian ini adalah untuk mengetahui bahwa ekstrak metanol buah pepaya dapat diformulasikan menjadi sediaan masker wajah gel peel off dan menentukan konsentrasi polivinyl alkohol (PVA) yang merupakan bahan dasar masker gel peel off yang memiliki sifat fisik, kimia, dan aktivitas antioksidan dengan nilai $\mathrm{IC}_{50}$ terbaik. Metode yang digunakan pada ekstraksi adalah maserasi dengan pelarut metanol. PVA yang digunakan dengan konsentrasi 2,5\%; 8,75\%; dan $17,5 \%$. Uji sifat fisik meliputi uji organoleptis, uji daya lekat, uji daya sebar, dan uji sifat kimia menggunakan uji $\mathrm{pH}$. Berdasarkan hasil penelitian, diperoleh hasil bahwa ekstrak metanol buah pepaya dapat diformulasikan menjadi sediaan masker wajah gel peel off, formula dengan konsentrasi PVA $8,75 \%$ memenuhi persyaratan organoleptik, daya lekat sebesar 20,16 detik $\pm 2,90$, daya sebar sebesar $10,2 \mathrm{~cm} \pm 1,28$, nilai $\mathrm{pH} 7,13$ dengan nilai $\mathrm{IC}_{50} 80,52 \mu \mathrm{g} / \mathrm{mL}$ yang termasuk antioksidan kuat.
\end{abstract}

Kata kunci: masker wajah gel peel off, ekstak metanol buah pepaya, PVA, $\mathrm{IC}_{50}$. 


\section{PENDAHULUAN}

$\begin{array}{crr}\text { Pada } & \text { masyarakat } & \text { Indonesia, } \\ \text { penggunaan } & \text { kosmetika } & \text { semakin }\end{array}$ meningkat, baik dalam bentuk maupun jumlahnya. Kosmetik merupakan suatu kebutuhan untuk tampil menarik serta sehat dan bugar. Formulasi dari bahan alam dalam bentuk sediaan kosmetika dapat meningkatkan kenyamanan dalam penggunaan dan penerimaan di masyarakat. Masker gel peel off merupakan salah satu alternatif sediaan yang dapat meningkatkan kenyamanan penggunaan dan diharapkan dapat meningkatkan aktivitas antioksidan dari buah pepaya yaitu dengan adanya pengaruh penggunaan basis masker gel peel off, yaitu polivinylalkohol (PVA). PVA merupakan bahan dasar masker gel peel off yang dapat digunakan yang memiliki keuntungan yaitu dapat menghasilkan gel yang homogen dengan bahan aktifnya dan dapat digunakan sebagai preparat kosmetik. Bahan dasar gel dengan formulasi yang tepat akan mempengaruhi kemampuan dalam menahan zat aktif. Masker gel peel-off adalah jenis masker yang akan mengering lalu membentuk lapisan film oklusif yang dapat dikelupas setelah digunakan. Masker gel peel-off dapat meningkatkan kelembapan kulit dan meningkatkan efek dari senyawa utama (senyawa aktif) pada bagian epitel dikarenakan oklusifitas lapisan polimer yang terbentuk (Shai, 2009; Vieira, 2009; Berighs dkk., 2013). PVA juga dapat melembabkan kulit, menggangkat sel kulit mati, dan membersihkan kulit (Chakraborty dkk., 2017). Konsentrasi PVA yang digunakan sebagai gelling agent pada 2,5\%-17,5\% (Andre, 2013). Sediaan dalam bentuk Liza pratiwi dan Sri wahdaningsih masker gel peel off memiliki keuntungan, yaitu mudah mengering dengan membentuk lapisan film yang mudah dicuci, dan memberikan rasa dingin dikulit (Lachman dkk., 1986).

Perkembangan teknologi sediaan obat yang berasal dari bahan alam semakin pesat. Sering dengan kemajuan ilmu pengetahuan dan teknologi, para ilmuan telah melakukan penelitian tentang khasiat tumbuhan obat, salah satunya tanaman yang bermanfaat sebagai antioksidan. Antioksidan merupakan suatu senyawa yang dapat melawan bahaya toksik serta mengurangi terjadinya kerusakan sel pada tubuh yang diakibatkan oleh proses oksidasi radikal bebas. Secara kimiawi, antioksidan adalah senyawa yang mampu memberikan elektron sehingga mencegah terjadinya proses oksidasi. Antioksidan alami mampu melindungi tubuh terhadap kerusakan yang disebabkan oksigen reaktif, mampu menghambat terjadinya penyakit degeneratif serta menghambat peroksidase lipid pada makanan. Antioksidan alami umumnya memiliki gugus hidroksi dalam struktur molekulnya. Salah satu tanaman yang mengandung vitamin $\mathrm{C}$ adalah buah pepaya (Carica papaya L.). Pepaya matang mengandung antioksidan yang lebih tinggi dibanding dengan pepaya mentah, dimana antioksidan yang terkandung antara lain senyawa fenol dan vitamin C (Austria dkk., 1996). Pepaya matang mengandung antioksidan yang lebih tinggi karena komponen-komponen antioksidan seperti betakaroten, vitamin C, likopen, dan zat lain telah terbentuk secara sempurna (Hernani dan Rahardjo, 2006). Pengujian in vitro antioksidan dengan metode DPPH pada ekstrak buah pepaya matang 
diperoleh nilai $\mathrm{IC}_{50}$ sebesar $33,6 \mu \mathrm{g} / \mathrm{mL} \pm$ 1,2 yang merupakan antioksidan yang sangat kuat (Dulce dkk., 2014). Efek antioksidan dan untuk perawatan kulit wajah akan lebih baik diformulasikan dalam bentuk topikal dibandingkan dengan oral karena zat aktif akan berinteraksi lebih lama dengan kulit wajah (Draelos dan Thaman, 2006). Tujuan penelitian ini adalah untuk mengetahui bahwa ekstrak metanol buah pepaya dapat diformulasikan menjadi sediaan masker wajah gel peel off, menentukan konsentrasi PVA yang memiliki sifat fisik dan kimia masker wajah gel peel off ekstrak metanol buah pepaya terbaik, dan menentukan aktivitas antioksidan dengan nilai IC $_{50}$. Keterbaruan penelitian yaitu pada sediaan masker wajah gel peel off yang diformulasikan dengan variasi PVA yang berasal dari bahan alami yaitu ekstrak metanol buah pepaya.

\section{METODE PENELITIAN}

\section{Alat dan Bahan}

Alat-alat yang digunakan dalam penelitian ini adalah: neraca analisis digital (Ohauss) empat angka dibelakang koma, alat-alat gelas (pyrex), stopwatch, spektrofotometer UV-Vis (Shimadzu tipe 2450), kuvet kuarsa ukuran $1 \mathrm{~cm}, \mathrm{pH}$ meter (HANNA), kertas saring, rotary evaporator (Heldolph tipe Hei-VAP), oven (Memmert), timbangan analitik (Precisa), waterbath (Memmert tipe WNB14), aluminium foil, kurs porselen, bejana maserasi, termometer, cawan penguap, desikator, mortir dan stamper.

Bahan-bahan yang digunakan dalam penelitian ini adalah: buah pepaya (perkebunan di Pontianak, Kalimantan Barat), kristal DPPH (Sigma-Aldrich) dan metanol (Merck) dengan kualitas pro Liza pratiwi dan Sri wahdaningsih analisis. Metanol (Bratachem), PVA (Bratachem), carbopol (Bratachem), propilen glikol (Bratachem), metil paraben (Bratachem) dengan kualitas farmasetis, dan aquadest (Dwicentra) dengan kualitas teknis.

\section{Jalannya Penelitian}

\section{Determinasi Tanaman}

Determinasi tanaman pepaya dilakukan di Laboratorium Biologi Fakultas Matematika dan Ilmu Pengetahuan Alam Universitas Tanjungpura dengan menyerahkan sampel berupa tanaman utuh dari akar, batang, daun, dan buah.

\section{Pengambilan dan Pengolahan Sampel}

Sampel yang digunakan adalah buah pepaya matang yang diambil dari perkebunan di Jalan 28 Oktober Siantan Pontianak, Kalimantan Barat. Pepaya yang matang berumur 8-10 bulan dan menunjukkan $3 / 4$ dari bagian buah berwarna kekuning kuningan serta getahnya encer dan berwarna bening (Rukmana, 1995). Buah Pepaya dicuci hingga bersih dengan air bersih dan mengalir kemudian dikupas kulitnya serta dibuang bijinya lalu buah pepaya dipotong-potong tipis dan dikering anginkan pada suhu $60^{\circ} \mathrm{C}$. Potongan pepaya yang telah kering kemudian dihaluskan dengan blender hingga terbentuk bubuk papaya (Alimia, 2012).

\section{Pembuatan Ekstrak Metanol Buah Pepaya}

Metode ekstraksi yang digunakan dalam penelitian ini adalah ekstraksi secara maserasi. Proses dilakukan terhadap buah pepaya yang telah berbentuk bubuk kering dengan cara menimbangnya terlebih dahulu kemudian dimasukkan ke dalam 
bejana maserasi dan ditambahkan pelarut metanol sampai semua sampel terendam oleh pelarut lalu ditutup dengan aluminium foil (Voigt, 1995). Proses maserasi dilakukan dengan mengganti pelarut setiap 24 jam dan dilakukan pengadukan tiga kali sehari. Proses ini dilakukan sampai pelarut menjadi bening. Hasil maserasi disaring untuk memisahkan filtrat dan residunya. Filtrat kemudian dipekatkan menggunakan rotary evaporator vacuum pada suhu $45^{\circ} \mathrm{C}$ (Alimia, 2012).

Formulasi masker wajah gel peel off ekstrak metanol buah pepaya

Adapun formula yang digunakan dapat dilihat pada tabel 1 (Andre, 2013):

Tabel 1. Formulasi masker wajah gel peel off ekstrak metanol buah pepaya

\begin{tabular}{lccc}
\hline \multicolumn{1}{c}{ Komposisi } & F I (g) & F II (g) & FIII (g) \\
\hline $\begin{array}{l}\text { Ekstrak metanol buah } \\
\text { pepaya }\end{array}$ & 0,03 & 0,03 & 0,03 \\
PVA & 2,5 & 8,75 & 17,5 \\
Propylene glikol & 6 & 6 & 6 \\
Carbomer 940 (carbopol) & 2 & 2 & 2 \\
Essense rose & 0,01 & 0,01 & 0,01 \\
Metil paraben & 0,18 & 0,18 & 0,18 \\
Water ad & 100 & 100 & 100 \\
\hline Keterangan: & & & \\
FI : Formula dengan konsentrasi PVA $2,5 \%$ & \\
FII : Formula dengan konsentrasi PVA $8,75 \%$ & \\
FIII : Formula dengan konsentrasi PVA $17,5 \%$ &
\end{tabular}

PVA dikembangkan ke dalam air panas sebanyak 20 kali beratnya selama 15 menit. Setelah mengembang digerus sampai transparan. Carbopol pada lumpang yang berbeda dikembangkan dengan air panas hingga homogen hingga jernih. Kemudian tambahkan metil paraben yang telah dilarutkan dalam propilenglikol. Dicukupkan dengan air suling sedikit demi sedikit dan digerus homogen hingga diperoleh dasar gel (Suardi dkk, 2008). Kemudian ditambahkan ekstrak ke dalam basis gel dan digerus hingga homogen.

Evaluasi Formula masker wajah gel peel off ekstrak metanol buah pepaya

Masker wajah gel peel off dievaluasi secara fisik dan kimia, yaitu meliputi organoleptis, daya sebar, daya lekat, dan uji $\mathrm{pH}$.

Liza pratiwi dan Sri wahdaningsih

\section{Organoleptik}

Pemeriksaan terhadap organoleptik yang dilakukan meliputi tekstur, warna dan bau yang diamati secara visual (Septiani, 2011).

\section{Uji daya sebar}

Ditimbang $500 \mathrm{mg}$ gel dan diletakkan di tengah kaca bulat berskala, sebelumnya ditimbang dahulu kaca yang lain dan diletakkan kaca tersebut di atas gel dan dibiarkan selama 1 menit. Kemudian diukur berapa diameter gel yang menyebar dengan mengambil panjang rata-rata diameter dari beberapa sisi. Kemudian ditambahkan 50,0 mg beban tambahan dan didiamkan selama 1 menit. Dicatat diameter gel yang menyebar dan diteruskan dengan menambah tiap kali beban tambahan 50,0 mg dicatat diameter 
gel yang menyebar selama 1 menit (Voigt, 1994).

\section{Uji daya lekat}

Dilakukan dengan meletakkan gel di atas objek gelas yang telah ditentukan luasnya. Diletakkan objek gelas lain di atas gel tersebut. Kemudian ditekan dengan beban $1 \mathrm{~kg}$ selama 5 menit. Objek gelas dipasang pada alat tes dan dilepaskan beban seberat 80 gram. Dicatat waktu yang diperlukan hingga objek gelas tersebut lepas.

\section{Pemeriksaan pH sediaan}

Sebelum digunakan, $\mathrm{pH}$ meter dikalibrasi dengan larutan bufer $\mathrm{pH} 7$ dan 4. Elektroda yang digunakan dibilas dengan aquades sebelum dan setelah pengukuran. Sebanyak 1 gram gel di encerkan dengan air suling hingga $10 \mathrm{~mL}$. Diambil larutan tersebut dan ditempatkan pada $\mathrm{pH}$ meter. Hasil $\mathrm{pH}$ akan muncul pada layar setelah beberapa saat. Campuran dihomogenkan dengan cara dibolak-balik selama 1 menit. Pembacaan pada alat $\mathrm{pH}$ meter dilakukan setelah 5 menit untuk memastikan angka sudah stabil dan tidak bergerak lagi (Froelich dkk., 2017).

\section{Uji Efektivitas Antioksidan terhadap DPPH}

Masing-masing larutan sampel (filtrat) sebanyak $2 \mathrm{ml}$ ditambahkan dengan $2 \mathrm{~mL}$ larutan DPPH 100 ppm, kemudian campuran larutan tersebut diinkubasi dalam penangas air tertutup pada suhu $37^{\circ} \mathrm{C}$ selama 30 menit, untuk selanjutnya diukur serapannya dengan spektrofotometri UV-Vis pada panjang gelombang 317 nm (Maisarah dkk., 2013).

\section{Analisis Data}

Pada uji daya sebar, luas penyebaran dihitung dengan rumus:

Liza pratiwi dan Sri wahdaningsih

$$
L=\pi . r^{2} \ldots \ldots \ldots \ldots . \quad \text {. (Pers. 1) }
$$

Keterangan:

$\mathrm{L}$ : Luas penyebaran

$\pi: 3,14$

$\mathrm{r}:$ jari-jari $(\mathrm{cm})$

Peredaman terhadap DPPH dihitung dengan menggunakan persamaan berikut (Wulansari dan Chairul, 2011):

$$
\mathrm{Q}=\frac{\mathrm{A}_{1}-\mathrm{A}_{2}}{\mathrm{~A}_{1}} \times 100 \%
$$

Keterangan:

$\mathrm{Q}=$ Persen Peredaman

A1 = Absorbansi Kontrol

A2 $=$ Absorbansi sampel

\section{HASIL DAN PEMBAHASAN \\ HASIL \\ Determinasi Tanaman}

Penelitian ini menggunakan sampel buah pepaya yang telah dideterminasi. Determinasi merupakan upaya untuk membandingkan suatu tumbuhan dengan satu tumbuhan lain yang sudah dikenal sebelumnya. Hasil determinasi berupa identitas suatu sampel tanaman yang diperlukan untuk menentukan objektivitas dan spesifitas suatu tanaman hingga pemanfaatannya dalam pengobatan dapat diperoleh. Hasil determinasi yang dikeluarkan Laboratorium Biologi, Fakultas Matematika dan Ilmu Pengetahuan Alam, Universitas Tanjungpura, Pontianak menunjukkan bahwa sampel yang digunakan pada penelitian ini adalah buah pepaya dengan spesies Carica papaya L. dari suku Caricaceae.

\section{Pengambilan Sampel}

Sampel yang digunakan dalam 
penelitian berupa buah dari tanaman pepaya (Carica papaya L.). Sampel yang digunakan pada penelitian ini berasal dari Jalan 28 Oktober, Pontianak, Provinsi Kalimantan Barat. Sampel diambil dari tanaman budidaya (kultivar) sehingga identitas jenis, lokasi tumbuh, keseragaman umur, serta masa panen tanaman dapat diketahui dengan jelas.

\section{Ekstraksi Buah Pepaya}

Ekstraksi merupakan salah satu proses pemisahan kimia dengan menggunakan pelarut yang sesuai untuk mendapatkan kandungan kimia yang sesuai pula. Tujuan dari ekstraksi adalah memisahkan sebanyak mungkin kandungan kimia agar lebih mudah digunakan dan dapat disimpan lebih lama. Oleh karena itulah pemilihan pelarut pada proses ekstraksi sangat penting karena dapat mempengaruhi zat aktif yang tersari dan mempengaruhi efek farmakologis yang akan dihasilkan. Pemilihan pelarut ini harus sesuai dengan prinsip dari penyarian zat aktif yaitu, like dissolve like. Kandungan zat aktif yang ingin disari memiliki sifat polar dan nonpolar yaitu, betakaroten, fenol dan vitamin $\mathrm{C}$ sehingga pelarut yang digunakan harus bersifat semipolar sehingga dapat menyari zat aktif tersebut. Metode ekstraksi yang digunakan dalam penelitian ini adalah metode maserasi. Maserasi dipilih karena dapat mengekstrak senyawa dengan baik dan dapat mencegah dekomposisi senyawa yang labil terhadap panas.

\section{Tabel 2. Hasil Maserasi dengan Pelarut Metanol}

\begin{tabular}{lllc}
\hline No. Hari & & \multicolumn{2}{c}{ Pengamatan Hasil Maserat } \\
\cline { 3 - 4 } & & \multicolumn{1}{c}{ Warna Maserat } & Jumlah Maserat \\
\hline 1 & Pertama & Larutan berwarna kuning muda & $850 \mathrm{~mL}$ \\
2 & Kedua & Larutan berwarna kuning cerah & $890 \mathrm{~mL}$ \\
3 & Ketiga & Larutan berwarna kuning cerah & $900 \mathrm{~mL}$ \\
& & Jumlah maserat & $2600 \mathrm{~mL}$
\end{tabular}

\section{Penetapan Susut Pengeringan}

Penetapan susut pengeringan bertujuan untuk menentukan batasan maksimal besarnya senyawa yang hilang pada proses pemanasan dengan suhu $105^{\circ} \mathrm{C}$. Penetapan susut pengeringan digunakan untuk mengetahui kadar air dan pelarut yang masih tersisa didalam ekstrak sehingga dapat diketahui golongan ekstrak. Parameter yang digunakan pada penetapan susut pengeringan ini adalah nilai bobot konstan dari ekstrak. Berdasarkan uji yang telah dilakukan diperoleh persen susut pengeringan sebesar $15,343 \%$. Hal ini menunjukkan bahwa ekstrak memiliki $15,343 \%$ zat yang dapat menguap dengan menggunakan pemanasan $105^{\circ} \mathrm{C}$. Hasil persentase ini menunjukkan bahwa ekstrak yang digunakan pada penelitian ini tergolong ekstrak kental. Ekstrak kental merupakan ekstrak dengan konsistensi yang liat pada keadaan dingin, sukar dituang dan persentase kandungan air dan pelarut dalam ekstrak mencapai 30\% (Voigt, 1995).

\section{Evaluasi Sifat Fisik dan Kimia Gel}

Evaluasi fisik dan kimia yang dilakukan meliputi pengamatan organoleptis, uji daya lekat, uji daya sebar, dan pengukuran $\mathrm{pH}$. Basis masker gel peel off dibuat dengan variasi gelling agent PVA. 


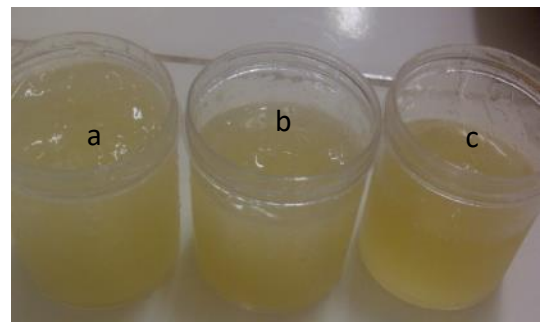

Gambar 1. Masker gel peel of dengan: a) konsentrasi PVA 17,5\%, b) konsentrasi PVA $8,75 \%$, dan c) konsentrasi PVA 2,5\%

Tabel 3. Hasil Pengamatan Organoleptis Gel

\begin{tabular}{ccccc}
\hline No & Formula & Warna & Bau & Tekstur \\
\hline 1 & F I & Kuning Transparan & Bau Khas Basis & Kental \\
2 & F II & Kuning Transparan & Bau Khas Basis & Sedang kental \\
3 & F III & Kuning Transparan & Bau Khas Basis & Sangat kental \\
\hline \multicolumn{5}{c}{ Keterangan: } \\
FI $\quad$ : Formula dengan konsentrasi PVA 2,5\% & \\
& FII & : Formula dengan konsentrasi PVA 8,75\% & \\
& FIII & : Formula dengan konsentrasi PVA 17,5\%
\end{tabular}

Pemeriksaan terhadap daya sebar dilakukan dengan tujuan untuk mengetahui kemampuan menyebar gel pada lapisan kulit. Gel dengan daya sebar yang baik akan mampu menyebar secara merata pada kulit sehingga efek yang dihasilkan merata. Adapun hasil uji daya sebar adalah pada tabel 4 berikut.

Tabel 4. Hasil Pengamatan Uji daya sebar

\begin{tabular}{cccc}
\hline & \multicolumn{3}{c}{ Rata -rata Luas penyebaran $\left(\mathbf{c m}^{\mathbf{2}}\right)$} \\
\cline { 2 - 4 } Beban $(\mathrm{g})$ & F I & F II & F III \\
0 & $27,25 \pm 1,94$ & $11,26 \pm 1,39$ & $7,78 \pm 0,75$ \\
50 & $35,23 \pm 14,96$ & $13,13 \pm 1,84$ & $8,82 \pm 0,70$ \\
100 & $36,45 \pm 15,46$ & $14,03 \pm 2,49$ & $9,64 \pm 1,10$ \\
150 & $38,41 \pm 15,63$ & $14,79 \pm 2,05$ & $7,79 \pm 1,36$ \\
200 & $41,34 \pm 17,63$ & $17,13 \pm 1,84$ & $10,2 \pm 1,28$ \\
\hline
\end{tabular}

Keterangan:

FI : Formula dengan konsentrasi PVA 2,5\%

FII : Formula dengan konsentrasi PVA 8,75\%

FIII : Formula dengan konsentrasi PVA 17,5\%

Hasil uji daya lekat menunjukkan kemampuan sediaan untuk dapat melekat pada kulit sehingga dapat melekat dengan baik pada kulit sehingga dapat memberikan efek yang maksimal. Sediaan yang dapat melekat dengan baik pada kulit juga akan mengoptimalkan penggunaan pada kulit dan menghindarkan pemakaian berulang. Adapun hasil uji daya lekat gel dapat dilihat pada tabel 5 . 
Tabel 5. Hasil Pengamatan Uji Daya Lekat

\begin{tabular}{cccc}
\hline No & \multicolumn{3}{c}{ Waktu } \\
\cline { 2 - 4 } $\mathbf{1}$ & F I & F II & F III \\
$\mathbf{2}$ & 3,15 detik & 17,25 detik & 1 menit 3,21 detik \\
$\mathbf{3}$ & 3,59 detik & 20,18 detik & 1 menit 1,17 detik \\
Rata- & 4,12 detik & 23,05 detik & 1 menit 4,13 detik \\
rata & 0,48 & 20,16 detik \pm & I menit 2,84 detik \pm \\
\hline
\end{tabular}

Keterangan:

FI : Formula dengan konsentrasi PVA 2,5\%

FII : Formula dengan konsentrasi PVA 8,75\%

FIII : Formula dengan konsentrasi PVA $17,5 \%$

Kemampuan melekat yang rendah menggambarkan bahwa sediaan mudah lepas dari kulit sehingga efek yang diberikan tidak maksimal. Pemeriksaan fisik terhadap kemampuan melekat menunjukkan bahwa gel pada F III memiliki daya lekat yang lebih lama daripada F I dan F II.
Pengujian sifat kimia gel yaitu dengan pengukuran $\mathrm{pH}$ dilakukan menggunakan $\mathrm{pH}$ meter. Sampel diletakkan pada $\mathrm{pH}$ meter bagian sensornya dan dibaca $\mathrm{pH}$ pada bagian monitor. Hasil pengukuran $\mathrm{pH}$ dapat dilihat pada tabel 6 .

Tabel 6. Hasil Pengukuran $\mathrm{pH}$

\begin{tabular}{cccc}
\hline No & \multicolumn{3}{c}{$\mathbf{p H}$} \\
\cline { 2 - 4 } $\mathbf{1}$ & $\mathbf{F ~ I ~}$ & $\mathbf{F ~ I I}$ & $\mathbf{F ~ I I I}$ \\
$\mathbf{2}$ & 7 & 7,1 & 7,2 \\
$\mathbf{3}$ & 7,1 & 7,2 & 7,2 \\
Rata-rata & $7,067 \pm 0,06$ & 7,1 & 7,3 \\
& & 0,06 & $7,23 \pm 0,06$ \\
\hline
\end{tabular}

Keterangan:

FI : Formula dengan konsentrasi PVA 2,5\%

FII : Formula dengan konsentrasi PVA $8,75 \%$

FIII : Formula dengan konsentrasi PVA 17,5\%

\section{Uji Aktivitas Penangkapan Radikal DPPH}

Aktivitas penangkapan radikal DPPH menggunakan parameter $\mathrm{IC}_{50}$. Hasil uji dapat dilihat pada Gambar 2. 


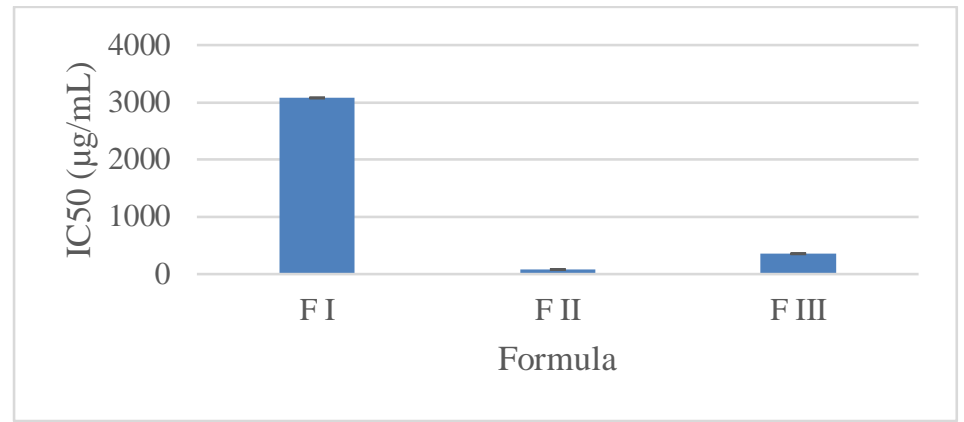

Gambar 2. Nilai $\mathrm{IC}_{50}$ Formula

\author{
Keterangan: \\ FI : Formula dengan konsentrasi PVA 2,5\% \\ FII : Formula dengan konsentrasi PVA 8,75\% \\ FIII : Formula dengan konsentrasi PVA 17,5\%
}

\section{PEMBAHASAN}

Pada ekstraksi, berdasarkan tabel 2 diketahui terjadi penurunan intensitas warna maserat. Hal tersebut menandakan senyawa yang disari oleh pelarut semakin sedikit. Prinsip ekstraksi menggunakan maserasi yaitu adanya difusi cairan penyari ke dalam sel tumbuhan yang mengandung senyawa aktif. Difusi tersebut mengakibatkan tekanan osmosis dalam sel menjadi berbeda dengan keadaan di luar. Senyawa aktif kemudian terdesak keluar akibat adanya tekanan osmosis di dalam dan di luar sel (Dean, 2009). Maserasi dilakukan didalam wadah kaca untuk mengurangi interaksi yang mungkin terjadi antara sampel dengan wadah. Pada proses maserasi dilakukan pengadukan sesekali. Pengadukan bertujuan untuk mempercepat penyarian, sehingga pelarut akan menembus dinding sel dan masuk ke dalam rongga sel yang mengandung senyawa aktif.

Fase yang terjadi pada awal proses maserasi adalah fase pembilasan komponen sel simplisia, dengan adanya kontak langsung pelarut dengan bagian Liza pratiwi dan Sri wahdaningsih simplisia yang telah rusak atau tidak utuh lagi akibat proses pengubahan bentuk. Oleh karena itu, dalam fase pertama maserasi ini, sebagian bahan aktif telah berpindah ke dalam bahan pelarut. Fase selanjutnya adalah fase ekstraksi pelarut untuk melarutkan komponen dalam sel yang tidak terluka dengan cara mendesak masuk kedalam sel. Pada fase ini terjadi pembengkakan sel simplisia, dimana membran mengalami pembesaran volume akibat masuknya pelarut. Fase ekstraksi sudah mulai terjadi pada hari pertama ditandai dengan simplisia yang telah mengembang.

Pelarut yang digunakan adalah metanol. Penggunaan metanol ini dipilih karena senyawa metanol dapat menyari lebih baik senyawa kimia. Metanol juga sangat efektif dalam menghasilkan jumlah bahan aktif yang optimal, dimana bahan pengotor hanya sedikit yang ikut ke dalam cairan pengekstraksi. Selain itu, metanol juga dapat menghambat kerja enzim dan dianggap lebih optimal karena proses maserasi dari bahan kering memerlukan pembasahan terhadap simplisia sehingga 
lebih optimal dibandingkan etanol $96 \%$ karena mengandung jumlah air yang lebih banyak. Pada penelitian lain, diperoleh total fenolik pada buah pepaya dengan pelarut metanol cukup tinggi yaitu 38,15\% $\pm 0,53$ (Asghar dkk., 2016). Maserat yang didapat kemudian diuapkan dengan penguap vakum putar (evaporator). Adapun prinsip dari penguapan dengan mengunakan rotary evaporator adalah menguapkan pelarut dengan cara menurunkan tekanannya. Labu evaporator dipanaskan pada temperatur tertentu di atas waterbath dan diputar selama evaporasi untuk mencegah terbentuknya gumpalan pada permukaan sampel sehingga terjadi pencampuran yang sempurna. Adanya tekanan yang diberikan oleh pompa vakum pada rangkaian rotary evaporator vaccum menyebabkan pelarut menguap dari campuran kemudian terkondensasi oleh labu kondensor dan jatuh pada labu penampung. Penguapan dihentikan bila ekstrak mulai terlihat pekat atau tidak lagi berkurang dan berhentinya tetesan pelarut pada labu penampung. Hasil ekstrak cair yang didapat dari proses evaporasi selanjutnya dikentalkan dengan menggunakan waterbath pada suhu \pm $60^{\circ} \mathrm{C}$.

Pengamatan organoleptis meliputi warna, bau, konsistensi serta sensasi yang dirasakan ketika dioleskan pada kulit. Hasil pengamatan organoleptis dapat dilihat pada tabel 3. Formula I, II, dan III berwarna kuning transparan. Hal tersebut dipengaruhi banyaknya ekstrak yang ditambahkan ke dalam basis yang berwarna putih. Semakin banyak ekstrak yang ditambahkan maka akan semakin pekat warnanya. Semua gel memiliki bau yang tajam, mudah merata ketika dioleskan dan tidak terasa panas. Formula Liza pratiwi dan Sri wahdaningsih
I, II dan III memiliki konsistensi yang baik. Berdasarkan tabel 3, diperoleh bahwa pada gel diperoleh penambahan diameter penyebaran berbanding lurus dengan penambahan beban. Hal tersebut menunjukkan bahwa gel memiliki daya sebar yang baik. Berdasarkan pengukuran $\mathrm{pH}$, diperoleh bahwa gel ekstrak metanol buah pepaya bersifat netral. Nilai $\mathrm{pH}$ tidak boleh terlalu asam karena dapat menyebabkan iritasi pada kulit sedangkan jika $\mathrm{pH}$ terlalu tinggi dapat menyebabkan kulit bersisik. pH gel yang baik yaitu 4,5-8 (SNI, 1996), sehingga dapat dikatakan bahwa gel ini memiliki $\mathrm{pH}$ yang baik sehingga tidak menyebabkan iritasi dan kulit bersisik. Sebelum digunakan, $\mathrm{pH}$ meter terlebih dahulu dikalibrasi menggunakan buffer standar $\mathrm{pH} 4$ dan 7 untuk memastikan bahwa hasil pengukuran dari alat tersebut dapat diterima atau baik.

PVA digunakan untuk memberikan efek peel off karena memiliki sifat adhesive atau bisa membentuk lapisan film yang mudah dikelupas setelah PVA mengering (Birck dkk., 2014). Hasil optimasi dari basis gel memperlihatkan bahwa semakin tinggi konsentrasi PVA yang digunakan maka viskositas sediaan semakin meningkat dan kualitas film yang terbentuk semakin baik. Pada penelitian lain, penggunaan PVA pada konsentrasi $14 \%$ diperoleh gel peel off sebagai formula terbaik (Priani dkk., 2015).

Berdasarkan pengujian, diketahui bahwa aktivitas pengkapan radikal bebas pada formula II termasuk dalam kategori kuat, formula III termasuk kategori kurang aktif namun masih berpotensi sebagai antioksidan, sedangkan formula I tidak berpotensi sebagai antioksidan. Uji aktivitas antioksidan menggunakan metode DPPH. Parameter yang digunakan adalah 
nilai $\mathrm{IC}_{50}$. Suatu senyawa dikatakan sebagai antioksidan sangat kuat apabila nilai $\mathrm{IC}_{50}$ kurang dari $50 \mu \mathrm{g} / \mathrm{mL}$, kuat apabila nilai $\mathrm{IC}_{50} 50-100 \mu \mathrm{g} / \mathrm{mL}$, sedang apabila nilai $\mathrm{IC}_{50} 100-150 \mu \mathrm{g} / \mathrm{mL}$, dan lemah apabila nilai $\mathrm{IC}_{50} 150-200 \mu \mathrm{g} / \mathrm{mL}$. Nilai IC IC $_{50}$ 200-1000 $\mu \mathrm{g} / \mathrm{mL}$ dinyatakan kurang aktif namun masih berpotensi sebagai antioksidan (Molyneux, 2004).

Berdasarkan hasil penelitian, pada formula II diperoleh nilai IC $_{50}$ paling kecil. Hal tersebut disebabkan oleh aktivitas penangkapan radikal DPPH dari senyawa fenolik dan flavonoid. Senyawa flavonoid berperan sebagai antioksidan karena memiliki gugus hidroksil yang dapat melepaskan proton dalam bentuk ion hidrogen. Ion hidrogen hanya memiliki satu buah proton dan tidak memiliki elektron, sehingga dalam elektron radikal yang terdapat pada atom nitrogen di senyawa DPPH berikatan dengan ion hidrogen dan menghasilkan DPPH yang tereduksi (Gurav dkk., 2007). Radikal pada DPPH dapat tereduksi ketika bereaksi dengan donor hidrogen yang terdapat dalam senyawa fenolik (Maisarah dkk., 2013).

Formula II memiliki nilai IC $_{50}$ yang kecil karena memiliki konsistensi gel yang tidak terlalu kental. Senyawa fenolik merupakan senyawa antioksidan yang dapat mendonorkan atom hidrogen kepada radikal bebas DPPH. Cairan pelarut dalam proses pembuatan ekstrak adalah pelarut yang optimal untuk senyawa kandungan yang berkhasiat atau yang aktif, dengan demikian senyawa tersebut dapat dipisahkan dari bahan dan dari senyawa kandungan lainnya, serta ekstrak hanya mengandung sebagian besar senyawa kandungan yang diinginkan. Faktor utama untuk pertimbangan pada pemilihan cairan Liza pratiwi dan Sri wahdaningsih penyari adalah selektivitas, kemudahan bekerja dan proses dengan cairan tersebut, ekonomis, ramah lingkungan dan keamanan (Depkes RI, 2000).

\section{KESIMPULAN}

Berdasarkan hasil penelitian dan pembahasan dapat disimpulkan bahwa:

1. Ekstrak metanol buah pepaya dapat diformulasikan menjadi sediaan masker wajah gel peel off.

2. Formula dengan konsentrasi PVA $8,75 \%$ memenuhi persyaratan organoleptik, daya lekat sebesar 20,16 detik $\pm 2,90$, daya sebar sebesar 10,2 $\mathrm{cm} \pm 1,28$, nilai $\mathrm{pH} 7,13$ dengan nilai $\mathrm{IC}_{50} \quad 80,52 \mu \mathrm{g} / \mathrm{mL}$ yang termasuk antioksidan kuat.

\section{SARAN}

Penelitian selanjutnya diharapkan dapat melakukan penelitian lebih lanjut menggunakan desain untuk memperoleh formula optimum dan menggunakan konsentrasi ekstrak yang lebih tinggi sehingga aktivitas antioksidan menjadi lebih besar.

\section{DAFTAR PUSTAKA}

Alimia, A M., dan Joni, K. 2012. Ekstraksi Antioksidan dari Buah Pepaya (Carica papaya L) dengan Menggunakan Metode Ultrasonic Bath (Kajian Tingkat Kematangan Pepaya dan Proporsi Volume Pelarut: Bahan). Malang: Universitas Brawijaya. 1-2.

Andre, B. 2013. Green clay and oloe vera peel of facial masks: response surface methodology applied to the formulation design. American Association of Pharmaceutical Scientists.14(1): 445-455. 
Asghar, N., Naqvi, S.A., Hussain, Z., Rasool, N., Khan, Z.A. 2016. Compositional difference in antioxidant and antibacterial activity of all parts of Carica papaya using different solvents. Chemistry Central Journal. 10 (5): 1-11.

Austria, R., Semenzato, A., dan Bettero, A. 1996. Stability of vitamin C derivatives in solution and topical formulations. Journal of Pharmaceutical Biomedical Analysis. 15(6): 795-801.

Berighs AO, Julia MR, Hellen KS, Rosane MB, dan Diva S. 2013. Green clay and aloe vera peel-off facial masks: response surface methodology applied to the formulation design. American Association of Pharmaceutical Scientists. 14(1):445-455.

Birck, C., Degoutin, S., Tabary, N., Miri, V., dan Bacquet, M. 2014. New crosslinked cast films based on poly (vinyl alcohol): preparation and physico-chemical properties. Express Polymer Letters. 8(12): 941-952.

Chakraborty, S., Vadakkekara, A., George, N., Bhagyasree, T., Mary, L. 2017. Application and Stability Evaluation of Polymer blends in Cosmetics. International Journal for

Research in Applied Science \& Engineering Technology. 5(9):849861.

Dean, J. 2009. Extraction Techniques In Analytical Science. London: John Wiley And Sons LTD. 43-46.

Departemen Kesehatan Republik Indonesia. 2000. Parameter Standar Umum Ekstrak Tumbuhan Obat. Jakarta: Departemen Kesehatan Republik Indonesia. 13-31.

Liza pratiwi dan Sri wahdaningsih
Draelos, Z.D., dan Thaman, L.A. 2006. Cosmetic Formulation of Skin Care Product. New York: Taylor and Francis Group.

Dulce, M., Pastrana, R., Gardea, A., Elhadi, M., Miguel, A., dkk. 2014. Effect of UV-C irradiation and low temperature storage on bioactive compounds, antioxidant enzymes and radical scavenging activity of papaya fruit. Journal of Food Science and Technology. 51 (12): 3821-3829.

Froelich, A., Osmalek, T., Snela, A., Kunstman, P., Jadach, B. 2017. Novel microemulsion-based gels for topical delivery of indomethacin: Formulation, physicochemical properties and in vitro drug release studies. Journal of Colloid and Interface Science. 507: 323-336.

Gurav, S., Deshkar, N., Gulkari, V., Duragkar, N., dan Patil, A., 2007. Free radical scavenging activity of Polygala chinensis Linn. Pharmacology. 2: 245253.

Hernani dan Rahardjo. 2006. Tanaman Berkhasiat Antioksidan. Jakarta. Penebar Swadaya. 2-6.

Lachman, L., Lieberman, H. A., dan Kanig, J. L. 1986. Teori dan Praktek Farmasi Industri. Edisi ketiga, diterjemahkan oleh: Suyatmi, S. Penerbit Universitas Indonesia. Jakarta. 760-779, 1514 - 1587.

Maisarah, A.M., Nurul, B., dan Asmah, R. 2013. Antioxidant analysis of different parts of Carica papaya. International Food Research Journal. 20 (3):10431048.

Molyneux, P. 2004. The use of the stable free radical diphenylpicrylhydrazyl (DPPH) for estimating antioxidant activity. Songklanakarin Journal of Science and Technology. 26: 211-219. 
Priani, S.E., Irawati, I., Darma, G. C. 2015. Formulasi Masker Gel Peel Off Kulit Buah Manggis (Garcinia mangostana, L). IJPST. 2 (3): 90-95.

Rukmana, R. 1995. Bertanam Pepaya. Yogyakarta: Penerbit Kanisius. 15-16, 25-36.

Shai, A. 2009. Handbook of cosmetic skin care. Edisi ke-II. USA. Informa Healt Care.

SNI-Standar Nasional Indonesia. 1996. Sediaan Tabir Surya. Jakarta. Badan Standarisasi Nasional.

Suardi, M., Armenia, dan Anita, M. 2008. Formulasi dan Uji Klinik Gel Anti Jerawat Benzoil Peroksida-HPMC. Skripsi. Fakultas Farmasi FMIPA UNAND.

Vieira, R.P. 2009. Physical and physicochemical stability evaluation of cosmetic formulations containing soybean extract fermented by bifidobacterium animalis. Brazilian Journal of Pharmaceutical Sciences. 45(3): 515-525.

Voigt, R. 1995. Buku Pelajaran Teknologi Farmasi. Penerjemah: Soendani Noerono Soewandhi. Yogyakarta. UGM Press. 561, 567-569, 577.

Wulansari, D dan Chairul. 2011. Penapisan Aktivitas Antioksidan dan beberapa tumbuhan Obat Indonesia Menggunakan radikal 2,2-Diphenyl-1 Picrylhydrazyl (DPPH). Majalah Obat Tradisional. 16 (1): 22-25. 